\title{
BECCS potential in Brazil: achieving negative emissions in ethanol and electricity production based on sugar cane bagasse and other residues
}

\author{
Moreira, José Roberto; Romeiro, Viviane; Fuss, Sabine; Kraxner, Florian; Pacca, Sérgio A. *
}

\begin{abstract}
Stabilization at concentrations consistent with keeping global warming below $2^{\circ} \mathrm{C}$ above the pre-industrial level will require drastic cuts in Greenhouse Gas (GHG) emissions during the first half of the century; net negative emissions approaching 2100 are required in the vast majority of current emission scenarios. For negative emissions, the focus has been on bioenergy with carbon capture and storage (BECCS), where carbon-neutral bioenergy would be combined with additional carbon capture thus yielding emissions lower than zero. Different BECCS technologies are considered around the world and one option that deserves special attention applies CCS to ethanol production. It is currently possible to eliminate 27.7 million tonnes $(\mathrm{Mt})$ of $\mathrm{CO}_{2}$ emissions per year through capture and storage of $\mathrm{CO}_{2}$ released during fermentation, which is part of sugar cane-based ethanol production in Brazil. Thus, BECCS could reduce the country's emissions from energy production by roughly $5 \%$. Such emissions are additional to those due to the substitution of biomass-based electricity for fossil-fueled power plants. This paper assesses the potential and cost effectiveness of negative emissions in the joint production system of ethanol and electricity based on sugar cane, bagasse, and other residues in Brazil. An important benefit is that $\mathrm{CO}_{2}$ can be captured twice along the proposed BECCS supply chain (once during fermentation and once during electricity generation). This study only considers BECCS from fermentation because capturing such $\mathrm{CO}_{2}$ is straightforward, thus potentially representing a cost-effective mitigation option for Brazil compared to other alternatives. The assessment shows that fuel prices would increase by less than $3.5 \%$ due to the adoption of BECCS from fermentation, while increasing investors' revenues are sufficient to compensate for the investment required. With appropriate government subsidies, or by sharing BECCS costs between all car fuels and all electricity supplied by hydro and bioelectricity, the increment in ethanol and electricity prices could be less than $1 \%$ for the final consumer. Meanwhile it would supply $77.3 \%$ of all cars' fuel (private cars) and $17.9 \%$ of all electricity in Brazil.
\end{abstract}


Carbon capture and storage (CCS) projects have been extensively discussed as a relevant strategy for reducing Greenhouse Gas (GHG) emissions. According to the Intergovernmental Panel on Climate Change (Edenhofer et al., 2014), this technology will play a vital role in reaching the required level of emission reductions in the future. ${ }^{1}$ In December 2010, the United Nations Framework Convention on Climate Change (UNFCCC) recognized, during the 16th Conference of the Parties (COP-16,) that CCS constitutes part of a relevant technology strategy for climate change mitigation and decided to include this option as a project activity under the Clean Development Mechanism (CDM) (UNFCCC, 2010). There are currently 55 CCS projects worldwide in progress, of which only 14 are active, as shown by the Global CCS Institute (GCCSI) at March, 2014 (GCCSI, 2014). Compared to fossil CCS, combining CCS with bioenergy (BECCS) has the special advantage of yielding negative emissions. For some biomass feedstocks, life cycle emissions are modest and when cogeneration is part of the process, emissions are quite low (EPA 2010). Adding $\mathrm{CO}_{2}$ capture to such systems might yield negative emissions.

Different technological approaches to BECCS are being considered around the world and one option that deserves special attention is the technology applied to sugar cane-based energy. The benefit of such a technology is that part of the primary energy is converted to ethanol via fermentation, which releases a relatively pure $\mathrm{CO}_{2}$ stream. Capturing $\mathrm{CO}_{2}$ at this stage presents a feasible opportunity to achieve negative emissions, making this technology an attractive option for mitigation in Brazil. Section 2 will give an overview of Brazil's national policy on climate change in this context.

The study's objective is to analyze the cost effectiveness of the suggested BECCS scheme in order to assess its attractiveness for Brazil's climate change mitigation portfolio, combining technological knowledge with economic costing of the BECCS chain. Section 2 presents the potential role of BECCS in Brazil and beyond. Section 3 analyzes a case study for Brazil, while policy implications will be discussed in Section 4. Section 5 concludes.

\section{The potential role of BECCS in Brazil and beyond}

\footnotetext{
${ }^{1}$ Note, however, that an update of their roadmap is pessimistic about the contribution of CCS to large-scale emissions reductions due to the low number of demonstration projects to date and the limited time left to achieve the necessary diffusion of CCS (IEA, 2012).
} 
In 2009, Brazil passed a law establishing its National Policy on Climate Change (BRAZIL, 2009) setting non-binding pledges to reduce Greenhouse Gas (GHG) emissions. Recently, more precise mitigation goals were established by the Brazilian Intended Nationally Determined Contribution (INDC). Brazil aims to reduce its emissions by $37 \%$ below 2005 levels by 2025, and possibly by $43 \%$ below 2005 levels by 2030 (UNFCCC 2015), which corresponds to roughly $1 \mathrm{GtCO}_{2}$.

Brazilian GHG reduction policies envision specific approaches to tackle different sectors, such as energy, forests, transportation, industry and agriculture. The Brazilian Federal Government has been able to accomplish a significant share of emission reductions by decreasing deforestation rates in Amazonia (Observatório do Clima, 2015). As of 2013, the federal government has succeeded in reducing GHG emissions by $76.7 \%$ in the Legal Amazon and $60.5 \%$ in the Cerrado Savannah. Besides nationwide carbon reduction targets, there are sub-national policies and mitigation goals in several Brazilian States. However, there are very few forests in São Paulo State, and other Southern and Southeastern states, in which most of the Brazilian economic activity takes place, so their potential to contribute to emission reductions through reduced deforestation is limited. Therefore, these regions have to consider other emission sources, and the use of other technologies, especially those related to the energy sector.

With over $80 \%$ of the electricity supply being renewable (EPE, 2013b), Brazil has one of the cleanest energy systems in the world; roughly $47 \%$ is from renewable sources compared to the world average of $19.5 \%$ (EPE, 2013a). Nevertheless, recent investments in Pre-Salt oil resource development might cause significant increases in oil and associated natural gas production ${ }^{2}$. Thus, energy is expected to become the major GHG emissions source beyond 2020. The Brazilian national oil and gas company (Petrobras) is investing in capturing the $\mathrm{CO}_{2}$ that escapes during the extraction process and injecting it for either enhanced oil recovery (EOR) or storage purposes in man-made reservoirs in the saline layer (Colby et al., 2011). This indicates the relevance of CCS as an important technology to reduce the country's GHG emissions in the mid- and long-term. Nevertheless, such projects are not targeting emissions from fossil fuel combustion, but focus on fugitive emissions from oil and gas extraction.

\footnotetext{
${ }^{2}$ This scenario is partially driven by the discovery of the Pre-Salt reservoirs, a major oil field that is estimated to contain at least 8 billion barrels of oil equivalent and associated gas, which will drive the country to triple its oil production (EPE, 2013a). The extraction of oil from the Pre-Salt layer is also expected to result in additional GHG emissions, since $\mathrm{CO}_{2}$ is present in the fluid in high concentration (10-15\%).
} 
Regarding BECCS, its main benefit for the country would be to take advantage of the Brazilian achievements with ethanol, as the fuel would become the first to provide negative emissions over its life cycle carbon balance (Pacca and Moreira, 2009). Brazil has a successful example of innovative energy policy in the Ethanol Fuel Program. BECCS investments could foster socio-economic development and environmental protection concurrently if incorporating sustainable biomass. For instance, rural economic development of sugar cane producing regions, and lower $\mathrm{CO}_{2}$ emission on the transportation sector results in better air quality in major cities. The demand for investments in the sugar/ethanol sector is significant, considering the high share of Brazilian sugar in the international market and the potential of ethanol demanded by the continuous increase of the flexfuel car fleet; and yet, it is unclear whether the sector has the financial capacity to meet demand. Even if the sugar and ethanol demand can be met, it is wise to remember the investment needed for additional bioelectricity. . Sugar cane based bioelectricity generation is already responsible for a significant share of electricity supply in the country (see Figure 1) and is expected to grow 6.7 times between 2010 and 2035 in the state of São Paulo (SAO PAULO, 2011). However electricity generation is investment-intensive and might be an exhausting drain on available resources. Financial resources for sugar cane are allocated in the following order: a) sugar; b) ethanol; c) bioelectricity; d) BECCS. Thus, the question arises whether BECCS can generate sufficient returns for the sugar/ethanol industry. Some possibilities include ethanol exports, e.g. of advanced ethanol to other markets such as the USA and certified ethanol to the European Union. Domestic ethanol demand will require an incentive scheme for BECCS-ethanol, blends, or bio-electricity. Therefore, it would be important to determine the economic impact of BECCS to sugar cane products and users.

In addition, the development of demonstration projects for BECCS technologies is still falling behind; a large-scale Brazilian BECCS project has been cancelled due to lack of financial support. This initiative was named "RCCS Project- Capture and Storage of $\mathrm{CO}_{2}$ deriving from the fermentation process of sugar into ethanol in the State of São Paulo". The choice of São Paulo was based on its high concentration of ethanol production (roughly $2 / 3$ of the national production). The project was designed to capture and store 1 million tonnes $(\mathrm{Mt}) \mathrm{CO}_{2}$ in a saline aquifer within 10 years, at a cost of US\$ 30 million. Although the Global Environmental Facility (GEF) would have funded $30 \%$ of the project, a lack of supplementary domestic financial support meant it did not become financially viable. 

available. For instance, some sugar mills in the Northeastern region have installed a system to capture $\mathrm{CO}_{2}$ from fermentation to use the gas in industrial applications (Furtado, 2014) ${ }^{3}$. Technically, this system could be coupled with the technology implemented by Petrobras, which pumps and stores $\mathrm{CO}_{2}$ underground ${ }^{4}$.

With this study, we demonstrate the prospects of a new technology - sugar cane-based ethanol production with electricity generation, where $\mathrm{CO}_{2}$ vented from fermentation is captured ${ }^{5}$. The mitigation potential thus arising for Brazil is important (a) for those regions within Brazil that cannot realize their emission reduction goals through reduced deforestation and (b) for Brazil's future climate change mitigation strategy that needs to take into account the ever rising portion of the country's GHG emission profile from energy generation. Finally, such a technology is also interesting for application in other parts of the world; this presents another important contribution of the paper. It is estimated that BECCS could reduce $\mathrm{CO}_{2}$ atmospheric concentrations by 0.5 to $1 \mathrm{ppm} / \mathrm{yr}$, sequestering 8 to $16 \mathrm{GtCO}_{2} / \mathrm{yr}^{6}$ (Cl-CDRRS, 2015)

\section{Case study: achieving negative emissions in sugar cane-based ethanol production and electricity generation}

\subsection{Previous studies}

Life-cycle GHG balances from ethanol production using sugar cane as feedstock have been published by different authors (Walter et al 2011, Souza, de Avila, and Pacca 2012). One of the most

\footnotetext{
${ }^{3}$ One example is the case of Brazilian bioethanol distilleries equipped with $\mathrm{CO}_{2}$ recovery systems from the NorthAmerican Pentair Haffmans Group, a company that has been selling its technology to breweries (which also generate the gas in the fermentation process and usually reutilize it) and to sugar cane mills in Brazil since 2009. The project relies on the system at the mills that is used for scrubbing ethanol from the vented gas post-fermentation, and adds piping and purification with activated carbon filters. The company has already supplied two systems for facilities in the State of Alagoas (Grupo Usineiro Toledo and Usina Penedo), and in the State of São Paulo (Usina Vale, a mill that produces sugar and alcohol and sells recovered $\mathrm{CO}_{2}$ ). The $\mathrm{CO}_{2}$ recovery system enables the plants to reduce $\mathrm{CO}_{2}$ emissions and concurrently generates additional income. The first system retrieves an average volume of $70 \mathrm{t} / \mathrm{day}$ and the second $35 \mathrm{t} /$ day.

${ }^{4}$ In 2013 Petrobras initiated a CCS project at commercial scale through $\mathrm{CO}_{2}$ injection for enhanced oil recovery off the Santos coast to test the carbonate reservoir behavior. The capture process is pre-combustion with direct injection, and the processing plant captures roughly $700,000 \mathrm{tCO}_{2}$ per year. Petrobras is also leading a pilot project in Miranga Field for $\mathrm{CO}_{2}$ separation from natural gas. (GCCSI, 2014).

${ }^{5}$ This $\mathrm{CO}_{2}$ is pure. The small amount of water and ethanol dragged by the $\mathrm{CO}_{2}$ flux is usually removed due to the ethanol's economic value. Essentially, there is no need for specific $\mathrm{CO}_{2}$ capture technology.

${ }^{6}$ For the specific BECCS technology described in this paper, essentially $\mathrm{CO}_{2}$ captured from ethanol fermentation, for each $\mathrm{kg}$ of ethanol produced from biological fermentation of sugars, $1 \mathrm{~kg}$ of $\mathrm{CO}_{2}$ is produced and captured. Considering the amount of ethanol commercialized as fuel for transportation by 2014- $93 \mathrm{Mm}^{3} / \mathrm{yr}$ (Licht, 2015), as much as $74 \mathrm{Mt}$ of $\mathrm{CO}_{2}$ could be captured.
} 
complete evaluations, considering domestic and global, direct and indirect land use change was performed by the US Environmental Protection Agency (EPA, 2010). According to that study, avoided GHG emissions due to gasoline substitution for ethanol in Brazil are $54 \mathrm{gCO}_{2} \mathrm{e} / \mathrm{MJ}$. Using sugar cane bagasse and other sugar cane residues to generate electricity fed into the grid yields even greater values. EPA (2010) finds that the emission of $91 \mathrm{gCO}_{2} / \mathrm{MJ}$ due to the use of liquid fossil fuel can be avoided because ethanol displaces gasoline, and bioelectricity displaces natural gas used in power plants, provided that the sugar mill uses modern efficient steam boilers (100 bar and $\left.535^{\circ} \mathrm{C}\right)$.

Nowadays, the total contribution of bioelectricity is modest when considering the average value of electricity delivered to the grid. Data available for 2012 shows that 20 TWh have been exported to the grid, for a sugar cane availability of $600 \mathrm{Mt}$ (BEN, 2013), yielding $33 \mathrm{kWh} / \mathrm{t}$ cane. The potential is greater: a survey carried out in 2011 concluded that the most efficient mills were generating around $100 \mathrm{kWh} / \mathrm{t}$ cane and exporting $75 \mathrm{kWh} / \mathrm{t}$ cane to the grid (CONAB, 2011). In reality, it is possible to generate $110 \mathrm{kWh} / \mathrm{t}$ cane using only bagasse and up to $220 \mathrm{kWh} / \mathrm{t}$ cane using bagasse and other available sugar cane residues with high pressure and high temperature steam boilers (Olivério, 2010). The full utilization of the bioelectricity potential is crucial to achieve negative emissions when BECCS is adopted.

\subsection{BECCS energy penalty and costs}

The GHG balance from the joint production and consumption of ethanol and bioelectricity is small (9 $\left.\mathrm{gCO}_{2} \mathrm{e} / \mathrm{MJ}\right)(\mathrm{EPA}, 2010)$ and could be further reduced to zero or below zero if $\mathrm{CO}_{2}$, which is released during fermentation and residue combustion, is captured and stored underground. Such an approach has been discussed since 2001, and its cost-effectiveness and $\mathrm{CO}_{2}$ reduction potential has already been evaluated (Möllersten et al, 2003). Nevertheless, a significant amount of energy is required for CCS, mainly for $\mathrm{CO}_{2}$ separation of the furnace's flue gas but also partly for $\mathrm{CO}_{2}$ compression.

Möllersten et al. (2003) conclude that the energy penalty due to CCS in the fermentation process is $0.12 \mathrm{kWh} / \mathrm{kgCO}_{2}$, whereas in the flue gas, from bagasse combustion, it is $0.31 \mathrm{kWh} / \mathrm{kgCO}$. The first alternative is less energy intensive because $\mathrm{CO}_{2}$ from sugar fermentation exits the reactor at atmospheric pressure and temperature around $37^{\circ} \mathrm{C}$ as a pure gas (99\%), free of contamination and proper for food and beverage manufacturing (Gollakota and McDonald, 2014). Thus, the only required treatment is the removal of water from the fumes (because the small amount of ethanol 
dragged by the released $\mathrm{CO}_{2}$ is usually separated in most sugar mills due its commercial value). The overall cost of capturing and storing $\mathrm{CO}_{2}$ from the two sources is US\$ $53 / \mathrm{tCO}_{2}$, and yet the study concludes that applying CCS to sugar fermentation is the less expensive option.

Consequently, we believe that it is worthwhile evaluating the costs of BECCS from fermentation in a typical sugar mill unit in Brazil, which, besides ethanol, also produces electricity from crop residues. This is possibly the most cost competitive BECCS alternative. We have combined technical coefficients from a typical sugar mill with data from a large-scale BECCS pilot project.

We assume a sugar mill processing 1,800 tonnes per day $(t / d)$ of sugar cane, but since it operates at $90 \%$, its nameplate capacity will be $2,000 \mathrm{t} / \mathrm{d}$. This corresponds to $4.63 \mathrm{Mt}$ of sugar cane processed per year assuming that the harvesting season comprises 208 days per year, of which only $90 \%$ of the days are effective ${ }^{7}$. Although sugar mills with such large capacities are rare in Brazil (see Figure 1), this capacity could easily be met by two facilities in the same vicinity. As shown in Figure 1, electricity cogeneration in sugar mills is always used as self-supply, and many mills also sell surplus electricity to the grid. Usually, electricity consumption in the sugar mills is around $30 \mathrm{kWh} / \mathrm{t}$ cane and over 100 units have installed capacity able to meet consumption and sell surplus electricity to the grid.

\footnotetext{
${ }^{7}$ Many factors prevent the sugar cane mill and associated facilities from working all days during the harvesting season. Some of them are as follows: intense precipitation that restricts transportation from the field to the mill, processing equipment failure either in the mill or in the cogeneration plant, and labour shortage in severe weather conditions.
} 


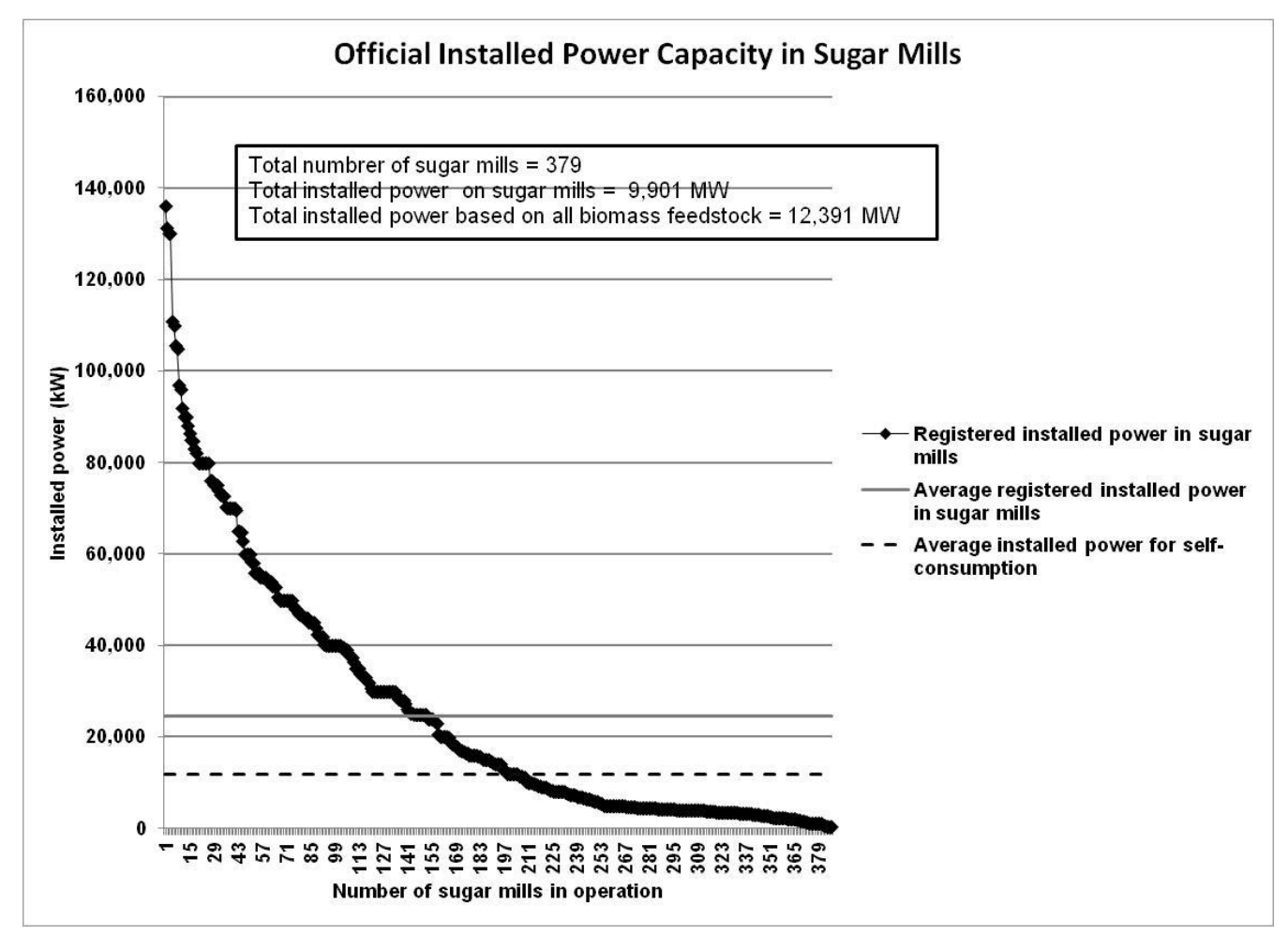

189 Figure 1. Distribution of cogeneration installed capacity of the 379 registered sugar mills in Brazil by 190 2014. Prepared by authors based on BIG (2015)

191 The project produces 1,729 tonnes of $\mathrm{CO}_{2}$ per day because fermentation yields $1 \mathrm{~kg}$ of ethanol and $1920.96 \mathrm{~kg}$ of $\mathrm{CO}_{2}$ and the specific gravity of hydrous ethanol is $0.809 \mathrm{~kg} / \mathrm{liter}$. At this point, it is useful 193 to note that $\mathrm{CO}_{2}$ emission from the combustion of sugar cane residues (usually $100 \%$ of the bagasse 194 and $50 \%$ of tops and leaves) is another possible candidate for CCS in sugar mills. This option is not 195 considered in this paper due its greater cost compared to $\mathrm{CO}_{2}$ from fermentation (Möllersten et al, 196 2003). Nevertheless, assuming the carbon content of dry biomass to be $50 \%$ of its weight, around 1970.37 tonnes $\mathrm{CO}_{2}$ would be produced from the combustion of 1 tonne of harvested cane. This value 198 can be compared to the $\mathrm{CO}_{2}$ released from fermentation of $0.070 \mathrm{tCO}_{2}$.

199 The parameters of the pumping system required to inject the daily production underground are 200 based on the Illinois Basin Decatur Project (IBDP) and the Illinois ICCS Project (Jones and McKaskle, 201 2014; Gollakota and McDonald 2014).

202 The total installed power of the system for handling 2,000 t/day of $\mathrm{CO}_{2}$ is $12,232 \mathrm{~kW}$. Therefore, the 203 energy penalty for pumping high pressure (14 Mpa) $\mathrm{CO}_{2}$ underground is $0.119 \mathrm{kWh} /$ liter of ethanol, 204 or $0.147 \mathrm{kWh} / \mathrm{kg}$ of ethanol. 
Such electricity can be provided by the sugar mill when processing ethanol, since it is commercially feasible to generate up to $208 \mathrm{kWh} / \mathrm{t}$ cane using all available bagasse plus a $50 \%$ share of residues (Olivério, 2010). Typical modern sugar mills in the South/Southeast of Brazil are designed to handle between 2 and $3 \mathrm{Mt}$ of cane per year, while a few manage around $6 \mathrm{Mt}$ of cane per year. Whatever their capacity, most of them convert roughly half of the cane to sugar and the other half to ethanol.

Assuming a conversion rate of $208 \mathrm{kWh} / \mathrm{t}$ cane, the total daily average generated electricity is 4,623 $\mathrm{MWh}$, equivalent to an installed power capacity of $238 \mathrm{MW}$ (assuming a 0.9 load factor).

With total power generation of 4,623 MWh/day, the compression requirement of $264 \mathrm{MWh} / \mathrm{day}$ represents a modest demand of $5.7 \%$. Electricity could be sold to the grid at US\$ 60/MWh, so this amounts to US\$ 3.3 million per year of foregone revenues. Another way to evaluate this cost is to quote it as an abatement cost of US\$ 9.16/ $\mathrm{tCO}_{2}$.

\subsection{Compression and storage cost}

Typically, compressor acquisition and its field installation are responsible for more than $50 \%$ of the total capital cost. At the Sleipner project (Torp and Brown, 2004), the total investment is quoted as US\$1996 96 million, from which US\$ 79 million is for the compressors and US\$ 15 million for the offshore injection well. For the Weyburn project total investment was US\$2000 10 million (Torp and Brown, 2004), but a split for each component is not provided. For the IBDP, total investment was US\$ 208 million (Gollakota and McDonald 2014), but, again, the split is not available. A presentation at the 2012 NETL CO 2 Capture Technology Meeting (Koopman 2013) quotes installed cost of high capacity and high pressure compressors as: 10 -stage $6000 \mathrm{hp}, \$ 8.0$ million at $\$ 1350 / \mathrm{hp}$, pressure ratio $200: 1$ at 1.70 per stage; 8 -stage $20,000 \mathrm{hp}-\$ 15.0$ million at $\$ 750 / \mathrm{hp}$ and $\$ 23.0$ million when installed at $\$ 1150 / \mathrm{hp}$, pressure ratio $143: 1$ at 1.86 per stage, for commercial units. We estimate that the total investment in compressors is US\$ 59.24 million, and the underlying assumptions are provided in the supplementary material.

The injection well cost depends on the existence of a proper geological reservoir at least 1,200 m below surface (USDoE, 2010). This requirement matches with information available for a geological formation below the Guarani aquifer. This freshwater reservoir extends continuously from the middle of the state of São Paulo (SP) to the state of Mato Grosso do Sul (MS), Parana and Santa Catarina, reaching parts of Paraguay and Argentina. Its depth is around a few hundred meters in the 
middle of the state of SP and goes deeper than 1,200 $\mathrm{m}$ at the border of SP with MS (see Figure 2).

Its water is exploited by many cities in both states, and due to the number of wells already installed, the geology of the region is well-known. Furthermore, we must use saline aquifers, which are known to exist below the Guarani reservoir, such as the Tubarão saline aquifer (see Figure 2). However, its rock porosity is not yet well studied. The cost of drilling a 1,200 m deep well is approximately US $\$ 500,000$. However, it might be necessary to drill at least 3 wells in order to find a reservoir with appropriate conditions, such as good rock porosity. Thus, the total cost of finding a well is $\$ 1,500,000$. In addition, in order to avoid contamination of shallower aquifers that are important drinking water sources (Piramboia and Botucatu) and in order to allow for the injection of pressurized $\mathrm{CO}_{2}$, the well must be insulated by a steel casing. This adds $40 \%$ to the cost of the successful well. Consequently, the total well cost is US $\$ 2,100,000$ (Hashiro, 2015).

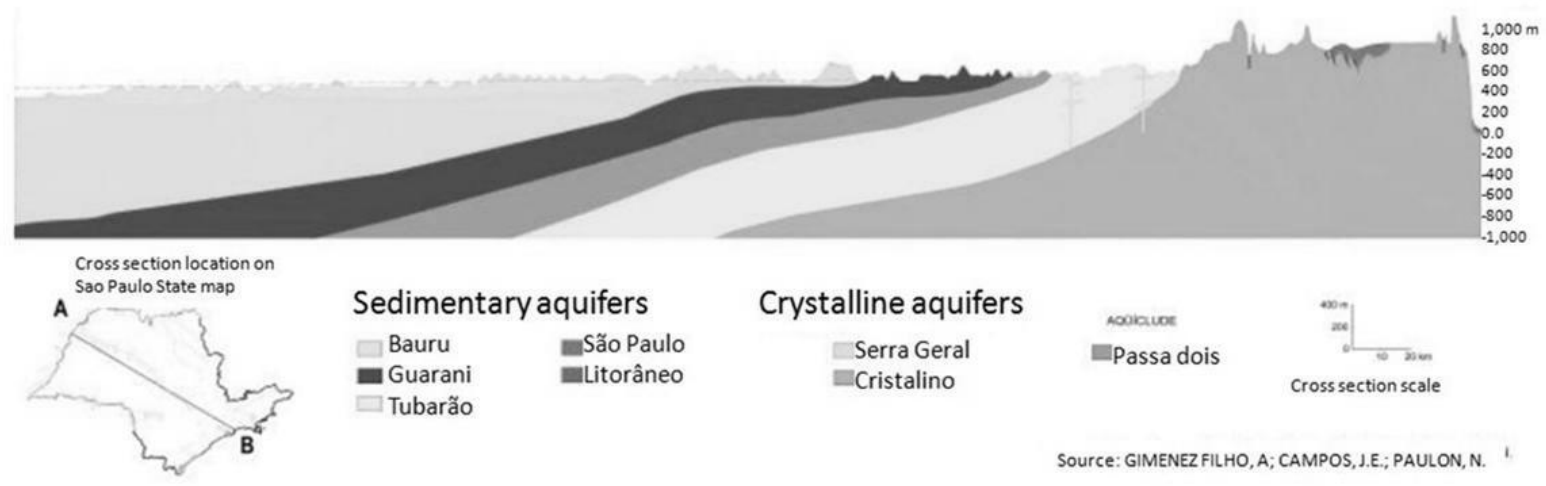

Figure 2: Hydrogeological profile of the state of São Paulo

Source: Altimetria: cartas do IBGE, escala 1:250.000; Limites geológicos: carta geológica do Brasil ao milionésimo, folhas Paranapanema (LOPES et al. 2004) e Rio de Janeiro (LEITE et al. 2004) Transportation cost is evaluated based on the assumption that existing saline aquifers are also continuously distributed over the same region of the Guarani aquifer. In addition there are around one hundred sugar mills distributed over an area of $200 \times 200 \mathrm{~km}$ in the Western part of SP state, which yields an average density of one per $400 \mathrm{~km}^{2}$. Given these two assumptions, a typical length of $10 \mathrm{~km}$ for a CCS pipeline is a reasonable figure. The total cost of a twenty $\mathrm{cm}$ diameter pipeline with $10 \mathrm{~km}$ length is US\$ 5 million (Knoope et al, 2013). Table S2 displays all investment costs considered in our analysis.

In our model, taking into account the significant proportion of hydroelectricity in the Brazilian electricity matrix ( $90 \%$ of the consumption, on average), we assumed that electricity used to power 
the CCS system will be supplied by the grid, instead of providing it through the sugar mill. This can be justified by: a) the need to avoid double-counting of the CCS cost, since the electricity generated at the mill will be more expensive than the power generated in sugar mills without CCS; b) providing a procedure to reduce the overall CCS cost, given that there is often excess hydroelectricity to guarantee the grid supply security and the CCS project does not need to operate continuously throughout the year or even every year; c) the fact that ethanol and bioelectricity production from sugar cane are not feasible during part of the year, since the sugar cane harvesting season is limited to 208 days per year. Thus, from the total investment cost quoted in Table S2, the value of US\$ 21.35 million, which is the cost for power generation used in CCS operation, is removed and replaced by an annual operational cost covering the expenses from hydroelectricity acquisition from the grid. Furthermore, it is important to add a value that represents maintenance costs of the complete system in particular compressors, to the operational cost of CCS. This cost is assumed to constitute $5 \%$ of the investment cost in compressors, i.e. US\$ 2.96 million/yr. Considering both of these operational costs, and assuming a lifetime of 18 years for the facility, the overnight construction of CCS comprises US\$ 6.65 million/yr and its operational cost is US\$ 3.31 million for annual electricity acquisition, at a unit cost of US\$ $60 / \mathrm{MWh}^{8}$. Thus, the total annual cost adds up to US\$ 9.99 million. The electricity acquisition value is discussed in the following subsection. Given all these cost assumptions, and considering that the total amount of $\mathrm{CO}_{2}$ handled by the CCS system is 360,236 tonne/yr, the full overnight CCS cost for the producer is US\$ $27.20 /$ tCO2. In comparison, a study done in Europe has found equivalent values of between US\$ 44-66/tCO2 for CCS projects applied to power plants (ZEP, 2015).

\section{Implications for policy support}

The sugar mill revenue from product sales is estimated to be $\$ 60 / \mathrm{MWh}$ (LEILÃO, 2013) and $\$ 0.6 /$ liter $^{9}$. CCS installation generates an additional producer cost of US\$ $30.29 / \mathrm{tCO}_{2}$, which is a realistic value when the financial costs of the sugar mill with CCS plus the economic return on the

\footnotetext{
${ }^{8}$ The average consumers' price of electricity in Brazil by 2012 was US\$169.58/ (FIRJAN, 2012). Considering the transmission and distribution prices, and taxes the average electricity sales price at the power plants were US\$ 43.81/MWh (EPE, 2013b: Instituto Acende Brasil, 2011). Considering hydroelectricity supply in 2012 was 415,000 GWh and thermoelectricity $112,000 \mathrm{GWh}$, the respective producer sales price were US\$38.37 and 63.95/MWh. Since the BECCS unit is expected to import mainly hydroelectricity the value assumed in this study is justified.

${ }^{9}$ The average sales prices of hydrous ethanol and anhydrous ethanol in 2012 at sugar mills without taxes were US\$ 0.567 and US\$ 0.644/liter, respectively (ANP, 2013). This yields an average ethanol sales price of US\$ 0.6015. Since in this study we are anticipating a greater increase in the use of ethanol than in gasoline, and a consequent increase in demand for hydrous, rather than anhydrous ethanol, the assumed value looks reasonable.
} 
284 investment is taken into account. Details on the calculation of the additional CCS cost are presented 285 in the supplementary material.

286 Based on these conditions we have evaluated four policy scenarios.

\subsection{Sharing the cost between ethanol fuel and bioelectricity}

288 Given that this cost is shared between both products, one possibility is to increase the bioelectricity production price by US\$1.49/MWh and the price of ethanol by US\$ $0.021 /$ liter. These are both sold at the sugar mill gate without taxes ${ }^{10}$. Comparing this to the price of ethanol at the pump in producing regions in Brazil (US\$ 0.953 and 1.123/liter for hydrous and anhydrous, respectively (ANP, 2013; PETROBRAS, 2015)) we can identify the value of other trading costs (distribution and retail), and taxes. The average generation sales price of electricity to final consumers represents $25.83 \%$ of the final price and the average taxes represent $45 \%$ of the final price (Institute Acende Brasil, 2011). Considering these costs and taxes occurring between the farm gate and end-users, the additional cost of CCS will be fully paid by ethanol consumers at US\$ $0.0334 /$ liter, increasing its price to US\$ 0.987 , or $3.50 \%$. Since a share of the $\mathrm{CO}_{2}$ cost is also included in the price of bioelectricity, this bioelectricity will be sold at US\$138.58/MWh, which means an increase of US\$2.716/MWh to final consumers (see Table 1).

\subsection{Sharing the cost between all light vehicles fuel consumers and all electricity consumers}

Actually, considering the important contribution of such a project for climate change mitigation, the cost increase might be paid not only by final hydrous ethanol consumers, but by all car users, regardless of fuel. In the country, the amount of gasohol sold represented $80.12 \%$ of total fuel used by Otto engines in 2012 (ANP, 2013), while the hydrous ethanol (92\% pure) takes the remaining share of $19.88 \%$; no neat gasoline is sold to final consumers. The gasohol is a blend of $20 \%$ anhydrous ethanol and $80 \%$ gasoline by volume ${ }^{11}$, at an average consumer price of US\$1.366/liter (ANP, 2013). Thus the 49.6 million cubic meters of liquid fuels used for cars are primarily composed of $64.10 \%$ gasoline, $19.88 \%$ hydrous ethanol (92\% pure), and $16.02 \%$ anhydrous ethanol ( $99.3 \%$ pure). Sharing the extra cost of US\$ 0.0334 /liter of ethanol across all these fuels, we conclude that

\footnotetext{
${ }^{10}$ The cost added by CCS can be shared between ethanol and bioelectricity sold by the mill. Several combinations of figures are possible, including charging all cost to either one of them. In this discussion, we choose one particular set of extra costs for electricity and ethanol.

${ }^{11}$ For many years gasohol has been a blend of $75 \%$ gasoline and $25 \%$ anhydrous ethanol. In particular, for 2012 the composition was $80 \%$ gasoline and $20 \%$ anhydrous ethanol.
} 
their final consumer prices would rise by US\$ 0.0066, which implies a hydrous ethanol relative price increase of $0.70 \%$. The price increase would be slightly higher for anhydrous ethanol and gasoline, which are sold at a higher price than hydrous ethanol (see car fuel price at Table 1). Our model assumes that BECCS might be adopted by two thirds of Brazilian sugar mills (400 Mt of sugar cane per year), so the share of hydrous ethanol could reach $77.3 \%$ of the total fuel used for passenger cars.

The increase in bioelectricity price to consumers could also be shared by all electricity consumers supplied by hydro and bioelectricity. Since the hydroelectricity supply is $415,000 \mathrm{GWh}$ and bioelectricity could provide $74,312 \mathrm{GWh}$ per year if $400 \mathrm{Mt}$ cane (two thirds of the total sugar cane harvested in 2012) were processed in BECCS modern sugar mills, the US\$2.716/MWh bioelectricity price increase would be distributed equally, in a percent basis, across all final electricity consumers at an average price of US\$ 0.474/MWh (see electricity price at Table 1 ).

\subsection{Government subsidy to bioenergy producers}

Another possibility is for a government subsidy or tax reduction to cover the estimated $\mathrm{CO}_{2}$ emission cost to society. By 2014, about 40 countries and over 20 sub-national jurisdictions have put a price on carbon. Assuming Brazil would accept a $\mathrm{CO}_{2}$ cost of US\$ $10 / \mathrm{tCO}_{2}{ }^{12}$, the net $\mathrm{CO}_{2}$ producer cost for BECCS would then be US\$19.93 $/ \mathrm{tCO}_{2}$. Under such a scenario, the additional cost of ethanol and bioelectricity at the sugar mill gate would be US\$ $0.0141 /$ liter of hydrous ethanol (or US\$0.0224 for the final consumer and US\$ 0.0044 when the extra cost is also shared with gasohol) and US\$1.819/MWh for bioelectricity consumers (or US\$0.276/MWh when the extra cost is also shared with hydroelectricity consumers), respectively. These last figures correspond to a relative increase in hydrous ethanol and bioelectricity consumer's price of $0.47 \%$ and of $0.20 \%$ for BECCS (see Table 1).

\subsection{Tax moratorium on prices increasing due to BECCS}

Another, more plausible, approach would be to negotiate a moratorium with governments on the taxing of price increases in liquid fuels used in passenger cars and bioelectricity sales to the grid due to CCS projects given their relevant and unique contribution to climate change mitigation. Since taxes charged on fuels and electricity are quite significant in Brazil, such an action would impact the

\footnotetext{
${ }^{12}$ Brazilian government has not shown willingness to provide direct environmental subsidy; therefore, we have adopted a modest value.
} 
final price of these energy carriers. To properly evaluate the extra cost of these energy carriers under this scenario, we have evaluated the market price of liquid car fuels in 2012 taking into account trading costs, taxes, and their values under the proposed government policy (Table S4).

341 Based on the assessed market values, we conclude that hydrous and anhydrous ethanol, as well as gasoline excess charges to cover CCS activities must increase on average by US\$ 0.0065/liter relative to the current cost. This means a price increase for the final consumer of $0.50 \%$ for hydrous ethanol and also for anhydrous and gasoline to cover the CCS deployment cost. It is important to remember that in our model this cost would be shared with electricity consumers; on top of these fuel price increases, bioelectricity and hydroelectricity prices for the final consumer must be increased, on average, by US\$ $0.261 / \mathrm{MWh}$ or $0.17 \%$ for bio- and slightly more for hydroelectricity, as shown on Table 1 and Table S5. This implies a cost, for the consumer, of US\$31.63/tCO for liquid fuels and US\$ 2.73/ $/ \mathrm{tCO}_{2}$ for electricity, which totals US\$34.36/tCO (see real BECCS price at Table 1 ).

Table 1- Impacts on the cost and prices of BECCS and in fuel and electricity due different government policies*

\begin{tabular}{|c|c|c|c|c|c|c|c|c|}
\hline & \multicolumn{3}{|c|}{ No Carbon Tax } & \multicolumn{3}{|c|}{ With Carbon Tax @ US\$10/tCO2 } & \multicolumn{2}{|c|}{ With Tax Moratorium } \\
\hline & $\begin{array}{c}\text { Producer } \\
\text { cost } \\
\text { increase }\end{array}$ & $\begin{array}{c}\text { Consumer } \\
\text { price } \\
\text { increase }\end{array}$ & $\begin{array}{c}\text { Shared } \\
\text { Consumer } \\
\text { price } \\
\text { increase }^{\text {a) }} \\
\end{array}$ & $\begin{array}{c}\text { Producer } \\
\text { cost } \\
\text { increase }\end{array}$ & $\begin{array}{c}\text { Consumer } \\
\text { price } \\
\text { increase }\end{array}$ & $\begin{array}{c}\text { Shared } \\
\text { Consumer } \\
\text { price } \\
\text { increase }^{\text {a) }} \\
\end{array}$ & $\begin{array}{c}\text { Consumer } \\
\text { price } \\
\text { increase }\end{array}$ & $\begin{array}{c}\text { Shared } \\
\text { Consumer } \\
\text { price } \\
\text { increase } \\
\end{array}$ \\
\hline Overnight BECCS cost (US\$/tCO2) & 27.200 & & & 17.200 & & & & \\
\hline Real BECCS price (US\$/tCO2) & 30.293 & 47.908 & 47.908 & 19.930 & 32.094 & 32.094 & 34.364 & 34.364 \\
\hline Bioelectricity (US\$/MWh) & 1.494 & 2.716 & 0.412 & 1.001 & 1.819 & 0.276 & 1.494 & 0.227 \\
\hline Ethanol (US\$/liter) & 0.0210 & 0.0334 & 0.0066 & 0.0141 & 0.0224 & 0.0044 & 0.0246 & 0.0048 \\
\hline Bioelectricity (\%) & $5.91 \%$ & $2.00 \%$ & $0.30 \%$ & $3.96 \%$ & $1.07 \%$ & $0.20 \%$ & $1.10 \%$ & $0.17 \%$ \\
\hline Ethanol (\%) & $3.50 \%$ & $3.50 \%$ & $0.70 \%$ & $1.48 \%$ & $2.35 \%$ & $0.47 \%$ & $2.58 \%$ & $0.50 \%$ \\
\hline Electricity (US\$/MWh) & & & 0.474 & & & 0.317 & & 0.261 \\
\hline Car fuel (US $\$ /$ liter) & & & 0.0088 & & & 0.0059 & & 0.0065 \\
\hline Electricity (\%) & & & $0.30 \%$ & & & $0.20 \%$ & & $0.17 \%$ \\
\hline Car fuel (\%) & & & $0.70 \%$ & & & $0.47 \%$ & & $0.50 \%$ \\
\hline
\end{tabular}

a) $\mathrm{CO} 2$ cost for electricity shared between bio and hydroelectricity supply; $\mathrm{CO} 2$ cost for ethanol shared between all cars'fuels

* Figures calculated by authors considering: ethanol w/ BECCS consumer price $=$ US $\$$

$0.621 /$ liter, financing interest rate $=2 \%$, equity share $=20 \%$, IRR on equity $=6 \%$

\subsection{Consequences for society}

354 Another way to put BECCS into perspective is by comparing its cost to other mitigation alternatives 355 in the country. In a recent assessment, the cost of emission reductions due to the production of 356 ethanol through cellulose hydrolysis was $37.64 \mathrm{US} \$ / \mathrm{tCO}_{2}$, whereas the cost of emission reductions 
due to new cogeneration projects that yield surplus electricity was 27.9 US\$/t CO 2 (Schaeffer, Szklo, de Gouvello, 2010). These values are comparable to the ones presented in our assessment.

We must realize that the construction of the first BECCS installations will probably involve extra costs, firstly because our assessment has not included some project items such as $\mathrm{CO}_{2}$ dewatering ${ }^{13}$, environmental licensing, project monitoring, geological site feasibility studies, etc. and secondly because the first-of-a kind project always carries some learning costs. Regarding the first point, it is reasonable to add some contingency reserves of about $20 \%$ of the evaluated cost shown in Table S2. As this is essentially an R\&D process, a case can be made for these costs to be borne by society.

Once successful, the BECCS project could be enlarged to take advantage of the existing ethanol producing logistics in Brazil. As discussed above, a significant share of investment expenditures are due to $\mathrm{CO}_{2}$ compression; the larger the volume of $\mathrm{CO}_{2}$ produced within the proximity of the storage site, the lower the investment costs. Indeed, compressor cost is strongly dependent on capacity.

Finally, a typical car using hydrous ethanol has an annual consumption of 1,650 liters of ethanol. Assuming a long term optimistic consumer cost of only US\$20/tCO technological improvement, instead of our calculated value (US\$ 47.91/ $\mathrm{tCO}_{2}$ - see Table 1) consumers, when using a BECCS facility similar to the one modelled in our case study (producing $2,225 \mathrm{~m}^{3}$ of ethanol/day, sequestering $1.729 \mathrm{tCO}_{2} /$ day), bear an annual expense of US\$ $6.24 / \mathrm{car}$, if BECCS cost is shared between all cars fuels. Regarding the bioelectricity price impact on consumers, it is necessary to note that average monthly electricity consumption by household is around 160 kWh. Due this CCS cost increase, consumers pay an electricity premium of US\$ $0.152 / \mathrm{MWh}$, with annual impact of US\$ 0.297 . Since residential consumption represents roughly a third of total consumption in the country, final direct and indirect annual cost of electricity to consumers total US\$ 0.963 per household. Looking at both the cost of liquid fuels and electricity, total annual expenses for carrying out this CCS program in Brazil would amount to US\$ 7.21 per household.

It is worthwhile noting that with this extra expense, $27.7 \mathrm{MtCO}_{2}$ would be removed from the atmosphere every year compared to the current baseline scenario. Assuming that a long-term cost

\footnotetext{
${ }^{13}$ Pipeline construction and operation costs are assumed to be small. According to Möllersten et al (2003), for a flow of $125 \mathrm{t} / \mathrm{hr}$ and a $50 \mathrm{~km}$ pipeline, the cost is US\$ 7-10/tCO . For this project, the flow is $100 \mathrm{t} / \mathrm{hr}$, but the pipeline is assumed to measure less than $10 \mathrm{~km}$ (see Jones and McKaskle, 2014). Furthermore, the energy required for $\mathrm{CO}_{2}$ transportation and equipment (low pressure compressor) has already been included in our cost calculation as shown in Table S2. Thus, even considering US dollar inflation in the period 2003/2013, the transportation cost is similar to the value estimated by Möllersten et al. (2003).
} 
of US\$ $20 / \mathrm{tCO}_{2}$ is achievable, this represents US\$ 554 million/yr. According to the IPCC's Fifth Assessment Report (Edenhofer et al., 2014) the achievement of $\mathrm{CO}_{2}$ atmospheric concentration stabilization at $550 \mathrm{ppm}$ requires emission reductions between 50 and $15 \mathrm{GtCO}_{2} / \mathrm{yr}$ from 2010 to 2100. The cost of achieving this is $0.04 \%$ of World GDP (US\$ 70 trillion). Put differently, the reduction must be $1.3 \% / \mathrm{yr}$ or $650 \mathrm{MtCO}_{2} / \mathrm{yr}$ in the initial years, at a cost of US\$ 28 billion/yr or US\$ $43.1 / \mathrm{tCO}_{2}$. Putting the results of this study roughly into context, if all mitigation was based on ethanol $\mathrm{CO}_{2}$ fermentation CCS, the cost would be US\$ 13.0 billion/yr or less than $50 \%$ of the IPCC estimates.

\section{Conclusion}

This paper has presented a case study on a BECCS scheme, where CCS is applied to $\mathrm{CO}_{2}$ vented from a Brazilian ethanol fermentation installation using ethanol by-products (bagasse and other sugar cane residues). The by-products are used for the production of heat and bioelectricity selfconsumption, as well as for third parties users through the electric grid. Ethanol produced from such a BECCS plant must be sold to final consumers at US\$ $0.0334 /$ liter above the regular ethanol price, which translates into a price increase of $3.50 \%$. Bioelectricity price also increases by US\$ 2.716/MWh, which corresponds to a $2.00 \%$ increase in the current market price.

Alternatively, the extra cost of the ethanol could be charged to the gasoline blend rather than the ethanol alone. Blended gasoline is one part ethanol and five parts gasoline, and consumers would pay an extra charge of US\$ $0.066 /$ liter to compensate the BECCS ethanol producer. This is found to be sufficient for the BECCS investor to be attracted to the BECCS system investment. An increase of US\$ 0.066 /liter represents a $0.70 \%$ increase in the price of hydrous ethanol and a little more in the blended gasoline price. Similarly, the bioelectricity incremental cost due to BECCS could be distributed across electricity supplied through hydropower, which is the cheapest electricity source in the country. This would generate an average increase in bio- and hydroelectricity prices of US\$ $0.412 / \mathrm{MWh}$ (see Table 1) representing a relative increase of $0.30 \%$ for bioelectricity and slightly more price increase for hydroelectricity.

In addition, we discussed the possibility of government subsidies. One option is for a US\$10/tCO premium to be paid to the mill owner and the other is a government moratorium on taxing additional costs of ethanol and bioelectricity from a BECCS sugar mill. Both options imply a small final price increase to the consumer, with the latter option being the most favorable one. Ethanol prices would be increased by US\$0.048/liter or $0.50 \%$, while the electricity price would show an 
414 increase of US\$0.261/MWh (0.17\%). This translates into an additional annual cost of US\$12.38 per 415 household in Brazil. In conclusion, the proposed technology, where $\mathrm{CO}_{2}$ is captured from 416 fermentation alone, is not far from being economical, and further research into this area is 417 warranted. Capturing the $\mathrm{CO}_{2}$ released from the sugar mill furnaces should also be examined as, 418 with a CCS efficiency of $100 \%$, this could capture $628 \%$ more $\mathrm{CO}_{2}$ than the amount calculated in this 419 study. In this way negative emissions could be pushed even further. 


\section{References}

42AANP -Agência Nacional de Petróleo, Gás Natural e Biocombustíveis, 2013. BOLETIM ANUAL DE 424 PREÇOS 2013 - preço $s$ d o petról e o, gás $n$ atura l e com b u s t í v e i s nos mer cados 425 nacional e internacional, Ministry of Mines and Energy, Rio de Janeiro, Brazil

42BEN - Brazilian Energy Balance, 2013. Published by Ministry of Mines and Energy, Brasilia, 427 Brazilhttps://ben.epe.gov.br/downloads/Relatorio_Final_BEN_2013.pdf

42BIG - Banco de Informações de Geração, 2015. Prepared by National Agency of Electric Energy 429 (ANEEL), Brasilia, Brazil 430 http://www.aneel.gov.br/aplicacoes/capacidadebrasil/energiaassegurada.asp. Accessed on 431 February 6, 2016

43BRAZIL. National Policy on Climate Change (PNMC), 2009. Available at 433 http://www.planalto.gov.br/ccivil_03/_ato2007-2010/2009/lei/l12187.htm

436I-CDRRS - Climate Intervention: Carbon Dioxide Removal and Reliable Sequestration, 2015. 435 Washington, D.C.: National Academies Press. http://www.nap.edu/catalog/18805. Accessed: 436 February 01, 2016

43Colby, G.M. Griffin, T.R. Gupta, M.K. Miller, H.F. Nove, S.E. Sehlstedt, N.H. (2011) High Pressure 438 CO2 Compressor Testing for Tupi I, Tupi II and Tupi III, Presented at the 8th. Forum de 439 Turbomáquinas Petrobras, Rio de Janeiro, August 9-12, 2011. 440 http://www.google.com.br/url?sa=t\&rct=j\&q=\&esrc=s\&source=web\&cd=2\&cad=rja\&uact=8 441 \&ved=0CDcQFjAB\&url=http\%3A\%2F\%2Fwww.researchgate.net\%2Fpublication\%2F26764736 442 4_High_Pressure_CO2_Compressor_Testing_for_Tupi_1_Tupi_2_and_Tupi_3\&ei=C1EDVbLZJ 443 7eHsQTlqYCIAQ\&usg=AFQjCNGZ6H_U2vi8cpsgbF5NdALEnXTSOg (accessed on 04/01/2015)

44 CONAB - COMPANHIA NACIONAL DE ABASTECIMENTO, 2011. A Geração Termoelétrica com a 445 Queima do Bagaço da Cana-de-Açúcar no Brasil- Análise do Desempenho da Safra 2009/10, 446 Março 2011

44Zdenhofer O., R. Pichs-Madruga, Y. Sokona, S. Kadner, J. C. Minx, S. Brunner, S. Agrawala, G. 448 Baiocchi, I. A. Bashmakov, G. Blanco, J. Broome, T. Bruckner, M. Bustamante, L. Clarke, M. 449 Conte Grand, F. Creutzig, X. Cruz-Núñez, S. Dhakal, N. K.Dubash, P. Eickemeier, E. Farahani, 450 M. Fischedick, M. Fleurbaey, R. Gerlagh, L. Gómez-Echeverri, S. Gupta, J. Harnisch, K. Jiang, F. 451 Jotzo, S. Kartha, S. Klasen, C. Kolstad, V. Krey, H. Kunreuther, O. Lucon, O. Masera, Y. 452 Mulugetta, R. B. Norgaard, A. Patt, N. H. Ravindranath, K. Riahi, J. Roy, A. Sagar, R. Schaeffer, 453 S. Schlömer, K. C. Seto, K. Seyboth, R. Sims, P. Smith, E. Somanathan, R. Stavins, C. von 454 Stechow, T. Sterner, T. Sugiyama, S. Suh, D. Ürge-Vorsatz, K. Urama, A. Venables, D. G. 455 Victor, E. Weber, D. Zhou, J. Zou, and T. Zwickel, 2014: Technical Summary. In: Climate 456 Change 2014: Mitigation of Climate Change. Contribution of Working Group III to the Fifth 457 Assessment Report of the Intergovernmental Panel on Climate Change [Edenhofer, O., R. 458 Pichs-Madruga, Y. Sokona, E. Farahani, S. Kadner, K. Seyboth, A. Adler, I. Baum, S. Brunner, 459 P. Eickemeier, B. Kriemann, J. Savolainen, S. Schlömer, C. von Stechow, T. Zwickel and J. C. 460 Minx (eds.)], Cambridge University Press, Cambridge, United Kingdom and New York, NY, 461 USA. 
46EPA, 2010. "Renewable Fuel Standard Program (RFS2) Regulatory Impact Analysis". EPA-420-R463 10-006. Washington, DC: Environmental Protection Agency. 464 http://www.epa.gov/otaq/renewablefuels/420r10006.pdf.

465PE - Empresa de Pesquisas Energéticas, 2013a. Brazilian energy balance, 2013. Available at 466 https://ben.epe.gov.br/downloads/Relatorio_Final_BEN_2013.pdf

46EPE- Empresa de Pesquisas Energéticas, 2013b. Anuário estatístico de energia elétrica 2013, 468 Empresa Pesqisa Energética, Ministry of Mines and Energy, Brazil.

46Burtado, Marcelo. 2014. "Tecnologia Ambiental: Usinas Recuperam CO2." 470 http://www.quimica.com.br/pquimica/tecnologia-ambiental/tecnologia-ambiental-usinas471 recuperam-co2/.

476CCSI - Global Carbon Capture Storage Institute, 2015. Information about CCS projects around 473 the world in an interactive map. Available at 474 http://www.globalccsinstitute.com/resources/projects/map, accessed on January 25, 2015.

476CCSI - Global Carbon Capture Storage Institute, 2014. The Global Status of CCS: 2014, November 476 2014, https://www.globalccsinstitute.com/publications/global-status-ccs-2014, accessed on 477 January 25, 2015

478ollakota, S and McDonald, S. (2014) Commercial-Scale CCS Project in Decatur, Illinois 479 Construction Status and Operational Plans for Demonstration, Energy Procedia 63 ( 2014) $480 \quad 5986-5993$

48Haschiro, J., 2015. Personal communication to two of the authors (SP and JRM)

48⿷EA - International Energy Agency, 2012. Energy Technology Perspectives - Pathways to a Clean 483 Energy System. 2013. IEA Publications, 9 rue de la Fédération, 75739 Paris Cedex 15 484 http://www.iea.org/publications/freepublications/publication/ETP2012 free.pdf, accessed 485 on February 10, 2016

48ほnstituto Acende Brasi, 2011). Tarifas de Energia e os Benefícios da Regulação por Incentivos. 487 White Paper 3, São Paulo, 24 p, Edition No. 3, January 2011

48Bones, Rosalind A. and McKaskle, Ray W, 2014. Design and operation of compression system for 489 one million tonne CO2 sequestration test Greenhouse Gases: Science and Technology 2014 490 Vol: 4 (5):617-625, doi: 10.1002/ghg.1438

49knoope, M.M.J., A. Ramírez. A.P.C. Faaij, 2013. Economic optimization of CO2 pipeline 492 configurations, Energy Procedia 37 (2013) 3105 - 3112

49Roopman, Aaron. 2013. "Ramgen Supersonic Shock Wave Compression Technology" presented at 494 the 2012 NETL CO2 Capture Technology Meeting, Pittsburgh, PA. 495 http://www.netl.doe.gov/File\%20Library/events/2013/co2\%20capture/A-Koopman-

496 Ramgen-Supersonic-Shock-Wave-Compression.pdf (Accessed on 04/01/2015) 
49ZEILÃO, 2013. InfoLEILÃO No. 002 - 5o Leilão de Energia de Reserva - 23 de August 23rd. 2013.

498 Published by Electric Energy Commercialization Chamber of Brazil (CCEE),

499 www.ccee.org.br/ccee/documentos/CCEE 129252, accessed on February 10, 2016

500EITE, C. A. S. et al. Folha SF.23 - Rio de Janeiro. In: SCHOBBENHAUS, C. et al. (Ed.). Carta 501 geológica do Brasil ao milionésimo, Sistema de Informações Geográficas. Brasília: CPRM, 502 2004. (Programa Geologia do Brasil), with CD-ROM.

50BICHT, F. O., 2015. Cited in Renewable Fuels Association, Ethanol Industry Outlook 2008-2014 504 reports. Available at www.ethanolrfa.org/pages/annual-industry-outlook

50\$OPES, R. C. et al. Folha SF.22 - Paranapanema. In: SCHOBBENHAUS, C. et al. (Ed.). Carta 506 geológica do Brasil ao milionésimo, Sistema de Informações Geográficas. Brasília: CPRM, 507 2004. (Programa Geologia do Brasil), with CD-ROM.

508/öllersten, Kenneth, Jinyue Yan, and Jose R. Moreira. 2003. "Potential Market Niches for Biomass 509 Energy with CO2 Capture and storage-Opportunities for Energy Supply with Negative CO2 510 Emissions." Biomass and Bioenergy 25 (3): 273-85. doi:10.1016/S0961-9534(03)00013-8.

51@bservatório do Clima, 2015. Documento síntese [recurso eletrônico] : análise das emissões de 512 GEE no Brasil (1970-2013) e suas implicações para políticas públicas / Governos Locais pela 513 Sustentabilidade (ICLEI) ... [et al.]. - São Paulo : Observatório do Clima, 2015. 52 p. 514 http://mediadrawer.gvces.com.br/oc/original/sintese 2015.pdf accessed on February 10, 5152016

510livério, Jose. L., Vadson B. Do Carmo, Marcilio A. Gurgel, 2010. 27ㅇ. Congresso da Sociedade 517 Internacional de Tecnologias da Cana de Açúcar, Vera Cruz, Mexico, March 11, 2010.

51Bacca, S. \& Moreira, J.R., 2009. Historical carbon budget of the Brazilian ethanol program, Energy 519 Policy, 37, pp.4863-4873.

52Bentair Haffmans, 2011. Brazilian bioethanol distillery equipped with Co2 recovery plant from 521 Pentair Haffmans Know How. Available at http://www.pentair.com/news/multimedia522 resources/multimedia/images/4886.pdf

52BETROBRAS, 2015. Composição de preços ao consumidor, Based in data from ANP and 524 CEPEA/USP,

525 http://www.google.com/url?sa=t\&rct=j\&q=\&esrc=s\&source=web\&cd=2\&cad=rja\&uact=8\&v 526 ed=0CCgQFjAB\&url=http\%3A\%2F\%2Fwww.petrobras.com.br\%2Fpt\%2Fprodutos-e527 servicos\%2Fcomposicao-de-

528 precos\%2Fgasolina\%2F\&ei=XJUmVbWPKoi5sAXPkYCgBg\&usg=AFQjCNEqkgqgQuVNgQVsj6vR 529 W5TB2eYqZg, accessed by April 8, 2015

53BAO PAULO, State of Sao Paulo Government, 2011. Matriz Energética do Estado de Sao Paulo531 2035, Executive Summary, Secretaria de Energia do Estado de Sao Paulo, March 2011

538chaeffer, R., Szklo, A. de Gouvello, C. 2010. Synthesis Report - Energy - Low Carbon Emissions 533 Scenarios in Brazil. Energy Sector Management Assistance Program, The World Bank. 534 http://www.esmap.org/sites/esmap.org/files/Energy_English_final_09-12.pdf 
53Souza, Simone Pereira, Márcio Turra de Ávila, and Sérgio Pacca. 2012. "Life Cycle Assessment of 536 Sugarcane Ethanol and Palm Oil Biodiesel Joint Production." Biomass and Bioenergy 44 537 (September): 70-79. doi:10.1016/j.biombioe.2012.04.018.

538orp, T, and K.R. Brown, 2005. "CO2 Underground Storage Costs as Experienced at Sleipner and 539 Weyburn." In Proceedings of the 7th International Conference on Greenhouse Gas Control 540 Technologies (GHGT-7), 531-40. Vancouver, 541 http://faculty.jsd.claremont.edu/emorhardt/159/pdfs/2006/Torp.pdf.

54Dnited Nations Framework Convention on Climate Change (UNFCCC, 2010) - Decision -/CMP.6 543 Carbon dioxide capture and storage in geological formations as clean development 544 mechanism project activities. Available at 545 http://unfccc.int/files/meetings/cop_16/application/pdf/cop16_cmp_ccs.pdf

546nited Nations Framework Convention on Climate Change (UNFCCC 2015) Brazilian Intended 547 Nationally Determined Contribution 548 http://www4.unfccc.int/submissions/INDC/Published\%20Documents/Brazil/1/BRAZIL\%20iN 549 DC\%20english\%20FINAL.pdf

55DSDoE - United Stated Department of Energy, 2010. Summary of the Methodology for 551 Development of Geologic Storage Estimates for Carbon Dioxide, Prepared for U.S. 552 Department of Energy, National Energy Technology Laboratory, Carbon Storage Program, 553 September 2010, 554 http://www.google.com.br/url?sa=t\&rct=j\&q=\&esrc=s\&source=web\&cd=1\&cad=rja\&uact=8 555 \&ved=0CCAQFjAA\&url=http\%3A\%2F\%2Fwww.netl.doe.gov\%2FFile\%2520Library\%2FResearc 556 h\%2FCoal\%2Fcarbon-storage\%2Fnatcarb\%2Fgeologic-storage-estimates-for-carbon557 dioxide.pdf\&ei=70kDVd37DbClsQSHhIJ4\&usg=AFQjCNG8Qc31a_xMqLX7mMHamfEWq0NtX 558

55Valter, Arnaldo, Paulo Dolzan, Oscar Quilodrán, Janaína G. de Oliveira, Cinthia da Silva, Fabrício 560 Piacente, and Anna Segerstedt. 2011. "Sustainability Assessment of Bio-Ethanol Production 561 in Brazil Considering Land Use Change, GHG Emissions and Socio-Economic Aspects." Energy 562 Policy 39 (10) (October): 5703-5716. doi:10.1016/j.enpol.2010.07.043.

56ZEP - Zero Emissions Platform, 2015. CCS for industry - modelling the lowest-cost route to 564 decarbonising Europe. European Technology Platform for fossil fuel power plants. 565 http://www.zeroemissionsplatform.eu/downloads/1564.html, accessed in February, 01, 2016 


\section{Supplementary material}

\section{Technical details of the $\mathrm{CO}_{2}$ compression system:}

The $\mathrm{CO}_{2}$ compression at the Illinois Basin Decatur Project (IBDP) consists of a centrifugal booster blower, four parallel 4-stage reciprocating compressors, a dehydration unit, and a centrifugal pump (Jones and McKaskle 2014). Table S1 shows the technical characteristics of the $\mathrm{CO}_{2}$ compression system.

TABLE S1: Technical characteristics of IBDP $\mathrm{CO}_{2}$ compression system

\begin{tabular}{|c|c|c|c|c|c|c|c|c|}
\hline & \begin{tabular}{|c|} 
Initial \\
pressure
\end{tabular} & $\begin{array}{c}\text { Initial } \\
\text { temperature }\end{array}$ & Enthalpy & $\begin{array}{c}\text { Final } \\
\text { pressure }\end{array}$ & $\begin{array}{c}\text { Final } \\
\text { temperature }\end{array}$ & Enthalpy & Power & Capacity \\
\hline & $\mathrm{MPa}$ & ${ }^{0} \mathrm{C}$ & $\mathrm{kJ} / \mathrm{kg}$ & Mpa & ${ }^{0} \mathrm{C}$ & $\mathrm{kJ} / \mathrm{kg}$ & $\mathrm{kW}$ & $\mathrm{tCO} 2$ \\
\hline Gas blower - 4 stages & 0.1 & 37.8 & 516.81 & 0.24 & 93.3 & 565.32 & 2238 & 2,000 \\
\hline Compressor 2, 1st stage & 0.24 & 35 & 513.17 & 0.52 & 145 & 612.64 & \multirow{4}{*}{2424} & \multirow{4}{*}{500} \\
\hline Compressor 2, 2nd stage & 0.52 & 35 & 510.72 & 1.71 & 156 & 617.99 & & \\
\hline Compressor 2, 3rd stage & 1.71 & 35 & 499.38 & 4.10 & 123 & 572.04 & & \\
\hline Compressor 2, 4th stage & 4.1 & 35 & 472.16 & 9.80 & 133 & 550.05 & & \\
\hline Centrif. Booster & 9.8 & 35 & 295.84 & 15.80 & & & 298 & 2000 \\
\hline
\end{tabular}

Source: Prepared by authors based on Gollakota, S and McDonald, S ,2014; Jones and McKaskle, 2014

\section{Cost assumptions for the compression system:}

1) A scale factor of 0.55 was adopted for the compression system;

2) Installation cost adds US\$ 400/hp to the 20,000 hp compressor, which is $53 \%$ of the compressor cost, and might be higher for smaller units.

Considering this project's $\mathrm{CO}_{2}$ injection rate $\left(1,729 \mathrm{tCO}_{2} /\right.$ day $)$ and the compressor configuration used in the IBDP project, it makes sense to use 4 four-stage 3,250 hp high pressure compressors, 1 gas blower of $3,000 \mathrm{hp}$ for the low pressure compressor and 1 centrifugal booster for final compression, with $400 \mathrm{hp}$.

3) For the high pressure compressor (3250 hp) cost is US\$ 11.06 million, including installation work, whereas only the compressor costs US\$ 6.15 million and installation costs US\$ 4.91 million.

4) For the low pressure compressor, with a capacity of 3,000 hp, the cost is obtained in the same way as the previous one, yielding a total compressor cost of US\$ 5.93 million plus 4.74 millions for installation - totaling US\$ 10.67 million.

5) For the centrifugal booster with a capacity of $400 \mathrm{hp}$, the same approach is used, yielding total costs of US\$ 4.31 (2.39 and 1.92) million.

Total compression system cost is US\$ 59.24 million (4X11.06+1X10.67+1X4.31).

Table S2 shows a complete cost of the CCS system considered in our analysis, including data already presented on the main text.

TABLE S2 -BECCS system costs in sugar mills in Brazil

\begin{tabular}{|l|c|c|}
\hline \multicolumn{1}{|c|}{ Equipment } & $\begin{array}{c}\text { Investment (Million } \\
\text { US }_{2012} \$ \text { ) }\end{array}$ & $\begin{array}{c}\text { Cost } \\
\text { share }\end{array}$ \\
\hline Compressors & 59.24 & $67.56 \%$ \\
\hline Power generation for CCS & 21.35 & $24.35 \%$ \\
\hline Injection well preparation & 2.10 & $2.39 \%$ \\
\hline Pipelines & 5.00 & $5.70 \%$ \\
\hline Total & 87.69 & $100.00 \%$ \\
\hline
\end{tabular}

Source: Prepared by authors 


\section{Real CCS cost to society}

598 In the main text, we have calculated overnight mitigation cost of $\mathrm{CO}_{2}$ due to a BECCS system 599 implemented in an efficient sugar cane mill, which collects and stores $\mathrm{CO}_{2}$ from sugar 600 fermentation. Nevertheless, society has to pay for the project cost and its revenue, because no 601 investor would be interested in the installation and operation of the proposed BECCS system. 602 In order to consider these aspects, plus the fact that the installation of modern sugar mills 603 entails the construction of an efficient electric plant that is able to produce and sell high 604 amounts of electricity to the grid while mitigating $\mathrm{CO}_{2}$ emissions from sugar fermentation, a 605 financial model was used.

606

607 608 609 610 611 612 613 614 615 616 617 618 619 620 621 622 623 624

The model considers the facility composed by: 1) a sugar mill without energy (heat and power) supply; 2) an electric power plant producing heat and power through cogeneration, which is the standard in all mills in Brazil; 3) the CCS system.

For the sugar mill, the investment cost is evaluated considering a value of US\$ 80 per tonne of cane processed per year (Marques, 2008) ${ }^{14}$, and $80 \%$ of the value is financed at $2 \%$ interest rate, over 16 years, with constant amortization values throughout the period.

For the modern electric power plant the investment cost is US\$1,756 per $\mathrm{kW}$ installed for a $60 \mathrm{MW}$ plant $^{15}$, and $80 \%$ is financed at the same conditions of the sugar mill. For the CCS system, total cost is quantified on Table S2 (except the US\$21.35 million that, as discussed in the main text, is unnecessary since electricity supply for CCS is acquired from the grid), and financed under the same conditions already discussed for the sugar mill and electric power plant.

Inflation is neglected and due to lack of regulation, installation depreciation cost is not accounted for. Revenues are accounted separately from ethanol sales, electricity sales, and, eventually, from the value attributable to CCS's $\mathrm{CO}_{2}$. Ethanol sales price at the sugar gate is assumed as US\$ 0.60/liter (ANP, 2013) without taxes; electricity sales price is assumed as US\$ 60.00/MWh, without taxes, for the facility operating without the CCS installation.; $\mathrm{CO}_{2}$ might be remunerated through carbon credit (typically, US\$ 10 to 20/tCO2, or another kind of subsidy discussed on the main text).

The model calculates Project's Internal Rate of Return (IRR) and Equity's IRR, assuming no inflation on values. Thus, real IRRs must be evaluated considering the calculated IRRs plus inflation. Therefore, interest rates for financing are low, while equity's IRR around $6 \%$ is considered attractive to investors.

The main parameters considered in the model are summarized on Table S3.

\footnotetext{
${ }^{14}$ This source concludes that the average investment cost for sugar cane mills ranges from 57 to 86 US\$/tcane in 2008. Considering all economic figures are quoted in US\$2012, we select values near the top of the range. Sensitivity evaluations were carried out for values of US\$ 75 t0 85/tcane, without any significant impact on our main conclusions.

${ }^{15}$ For other power capacity, an economic scaling factor of 0.75 is used to account for the cost per kW.
} 
Table S3: Economic - financial model assumptions (All monetary values in 2012 US\$)

\begin{tabular}{|c|c|}
\hline Sugar mill investment cost (US\$/tcane processed) & 80 \\
\hline Sugar mill financed investment (\%) & 80.00 \\
\hline Sugar mill financed interest $(\%)$ & 2.00 \\
\hline Sugar mill financed grace period (year) & 2 \\
\hline Sugar cane financed period (years) & 16 \\
\hline Sugar mill construction time (years) & 2 \\
\hline Ethanol sales price at sugar mill gate (US\$/itre) & 0.60 \\
\hline Sugar cane cost (\% of ethanol sales price) & 50 \\
\hline Sugar cane processing cost (\% of ethanol sales price) & 32 \\
\hline Sugar cane to hydrous ethanol (92\%) yield (litres) & 90 \\
\hline Sugar cane yield (tonnes/ha) & 100 \\
\hline Electricity plant investment (US\$/MW) & 1756 \\
\hline Electricity plant financed interest (\%) & 2.00 \\
\hline Electricity plant financed cost share $(\%)$ & 80 \\
\hline Electricity plant financed grace period (years) & 4 \\
\hline Electricity plant financed period (year) & 16 \\
\hline Electricity plant construction time (years) & 2 \\
\hline Acquired electricity cost for the CCS system (US $\$ / M W h$ ) & 60 \\
\hline
\end{tabular}

633 Table S4: Price profile due commercialization without BECCS and with BECCS cost shared 634 with all liquid fuels used in cars -moratorium taxation scenario 


\begin{tabular}{|c|c|c|c|c|c|c|}
\hline \multirow[b]{2}{*}{ Car fuel type } & \multicolumn{3}{|c|}{ Values for year $2012^{\mathrm{a})}$ (US $\$ /$ liter) } & \multicolumn{3}{|c|}{ BECCS cost shared with all car fuels ${ }^{a}$ (US $\left.\$ / l i t e r\right)$} \\
\hline & Hydrated eth. & Anhydrous eth. & Gasoline A & Hydrated eth. & Anhydrous eth. & Gasoline A \\
\hline Consumption share ${ }^{\mathrm{b})}$ & $19.880 \%$ & $16.024 \%$ & $64.096 \%$ & & & \\
\hline Fuel price at mill/refinery & 0.6000 & 0.6443 & 0.8183 & 0.6044 & 0.6488 & 0.8239 \\
\hline Distribution margin $^{\mathrm{c})}$ & $4.54 \%$ & $8.00 \%$ & \multirow{2}{*}{$17.00 \%$} & $4.54 \%$ & $8.00 \%$ & \multirow{2}{*}{$17.00 \%$} \\
\hline Service station margin ${ }^{c)}$ & $5.00 \%$ & $7.00 \%$ & & $5.00 \%$ & $7.00 \%$ & \\
\hline Disrt\&Service stat. price & 0.0910 & 0.1685 & 0.2425 & 0.0916 & 0.1697 & 0.2442 \\
\hline Taxes share ${ }^{\mathrm{c})}$ & $27.54 \%$ & $27.64 \%$ & $25.64 \%$ & $27.54 \%$ & $27.64 \%$ & $25.64 \%$ \\
\hline Taxes value & 0.2626 & 0.3105 & 0.3658 & 0.2644 & 0.3126 & 0.3683 \\
\hline Fuel for consumers ${ }^{\mathrm{c})}$ & 0.9536 & 1.1233 & 1.4266 & 0.9602 & 1.1311 & 1.4362 \\
\hline increase $^{\text {d) }}$ & & & & 0.0066 & 0.0078 & 0.0096 \\
\hline BECCS fuels overtaxes & & & & 0.0018 & 0.0022 & 0.0025 \\
\hline BECCS fuels taxes return & & & & 0.0018 & 0.0022 & 0.0025 \\
\hline $\begin{array}{l}\text { BECCS fuel real price } \\
\text { increase }\end{array}$ & & & & 0.0048 & 0.0057 & 0.0072 \\
\hline $\begin{array}{l}\text { BECCS fuels relative price } \\
\text { increase }\end{array}$ & & & & $0.50 \%$ & $0.50 \%$ & $0.50 \%$ \\
\hline $\begin{array}{l}\text { Average BECCS price } \\
\text { increase }\end{array}$ & & & & & 0.0065 & \\
\hline $\begin{array}{l}\text { Average BECCS relative } \\
\text { price increase }\end{array}$ & & & & & $0.50 \%$ & \\
\hline $\begin{array}{l}\text { Average BECCS price } \\
(\mathrm{US} \$ / \mathrm{tCO} 2)^{\mathrm{d})}\end{array}$ & & & & & 31.11 & \\
\hline
\end{tabular}

\begin{tabular}{|c|c|c|c|c|c|c|}
\hline & \multicolumn{3}{|c|}{ Values for year $2012^{\mathrm{a})}$ (US\$/iter) } & \multicolumn{3}{|c|}{ Values with BECCS applied to all car fuels ${ }^{\mathrm{a}}$ (US $\$$ /liter) } \\
\hline Car fuel type & Hydrated eth. & \begin{tabular}{|l} 
Anhydrous eth. \\
\end{tabular} & Gasoline A & Hydrated eth. & Anhydrous eth. & Gasoline A \\
\hline Consumption share $\left.{ }^{b}\right)$ & $19.880 \%$ & $16.024 \%$ & $64.096 \%$ & & & \\
\hline Fuel price at mill/refinery & 0.5670 & 0.6443 & 0.8183 & 0.5729 & 0.6500 & 0.8240 \\
\hline Distribution margin ${ }^{\mathrm{C}}$ & $7.00 \%$ & $8.00 \%$ & \multirow{2}{*}{$17.00 \%$} & $7.00 \%$ & $8.00 \%$ & \multirow{2}{*}{$17.00 \%$} \\
\hline Service station margin ${ }^{\mathrm{C})}$ & $6.00 \%$ & $7.00 \%$ & & $6.00 \%$ & $7.00 \%$ & \\
\hline Disrt\&Service stat. price & 0.1240 & 0.2041 & 0.2420 & 0.1253 & 0.1700 & 0.2442 \\
\hline Taxes share ${ }^{\mathrm{C})}$ & $27.54 \%$ & $27.64 \%$ & $25.64 \%$ & $27.54 \%$ & $27.64 \%$ & $25.64 \%$ \\
\hline Taxes value & 0.2626 & 0.3105 & 0.3658 & 0.2654 & 0.3133 & 0.3684 \\
\hline Fuel for consumers ${ }^{\mathrm{C}}$ & 0.9536 & 1.1233 & 1.4266 & 0.9636 & 1.1333 & 1.4366 \\
\hline increase $^{\text {d) }}$ & & & & 0.0100 & 0.0100 & 0.0100 \\
\hline BECCS fuels overtaxes & & & & 0.0028 & 0.0028 & 0.0026 \\
\hline BECCS fuels taxes return & & & & 0.0028 & 0.0028 & 0.0026 \\
\hline $\begin{array}{l}\text { BECCS fuel real price } \\
\text { increase }\end{array}$ & & & & 0.0073 & 0.0073 & 0.0075 \\
\hline $\begin{array}{l}\text { BECCS fuels relative price } \\
\text { increase }\end{array}$ & & & & $0.76 \%$ & $0.65 \%$ & $0.52 \%$ \\
\hline $\begin{array}{l}\text { Average BECCS price } \\
\text { increase }\end{array}$ & & & & & 0.0074 & \\
\hline
\end{tabular}

a) Values in US\$/liter when no unit shown; ${ }^{\text {b) }}$ ANP, 2013; ${ }^{\text {c) }}$ PETROBRAS, 2015;

${ }^{d)}$ Calculated with model described in text for BECCS hydrous ethanol producer price @ US\$ 0.621/liter, interest on financing share of $2 \% / y r, 20 \%$ equity share, and $6 \%$ internal rate of return on equity.

Table S5 displays typical average prices for commercial electricity sales, including transmission, distribution costs, and taxes. 
Table S5: Average cost composition of electricity to final consumers.

645

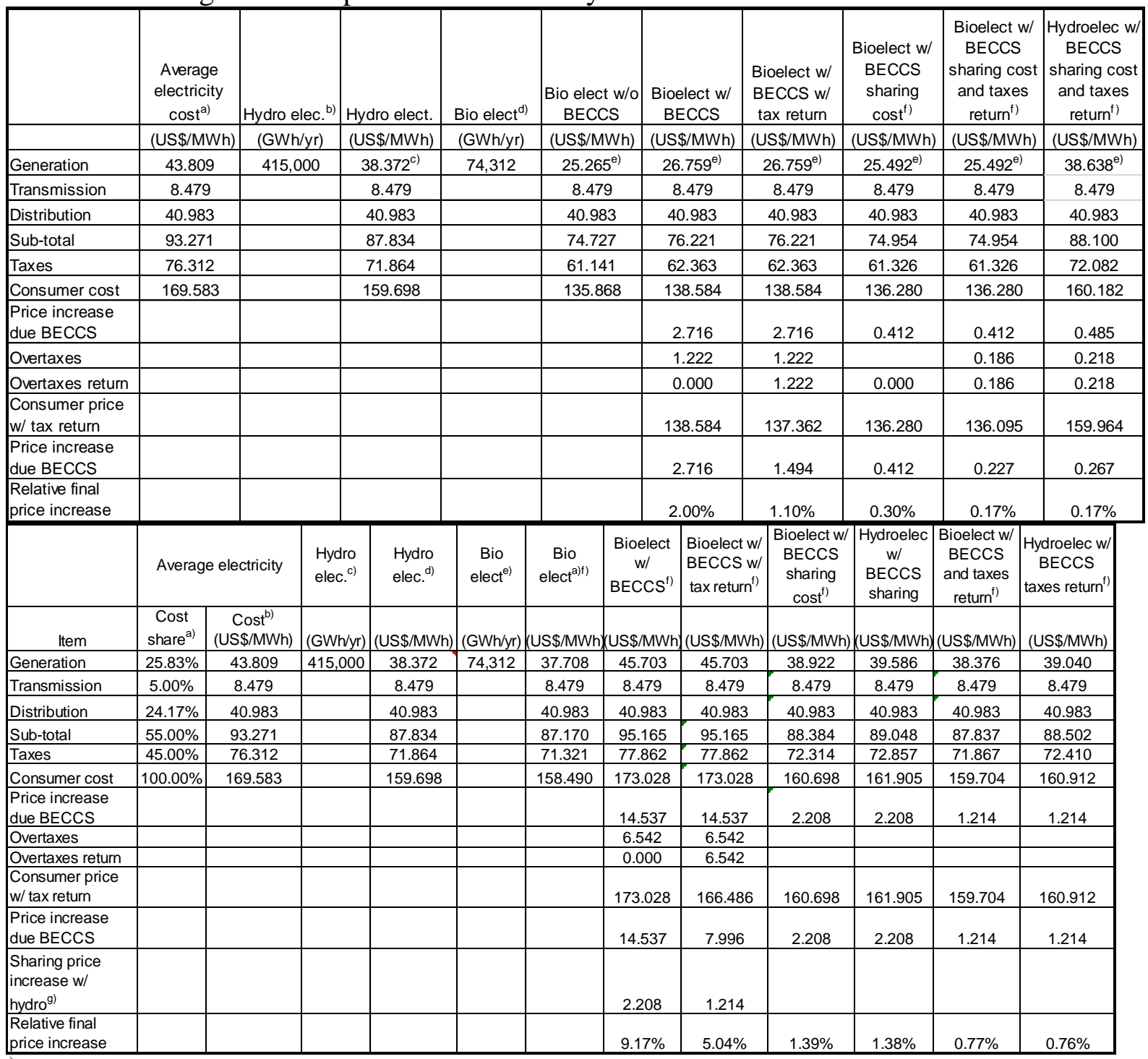

a) Calculated based in average electricity price (FIRJAN, 2012; Instituto Acende Brasil, 2011) and average

bidding hydroelectricity price (MME, 2012), as well as the share of hydro (415 TWh) and thermal power (132

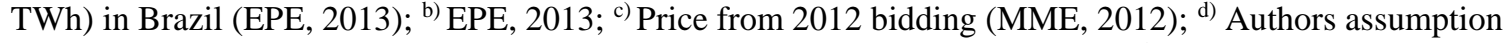
based in the installation of 86 BECCS mills processing $400 \mathrm{Mt}$ of sugar cane/yr; ${ }^{\text {e) }}$ Generation cost evaluated from authors' model discussed in the paper; when the BECCS is shared with ethanol priced at US\$ 0621/1 for the shared by all users of bio (74.3 TWh) and hydroelectricity (415 TWh). Source: Compiled by authors. 
Figure S1 synthesize some results from our model.

656 


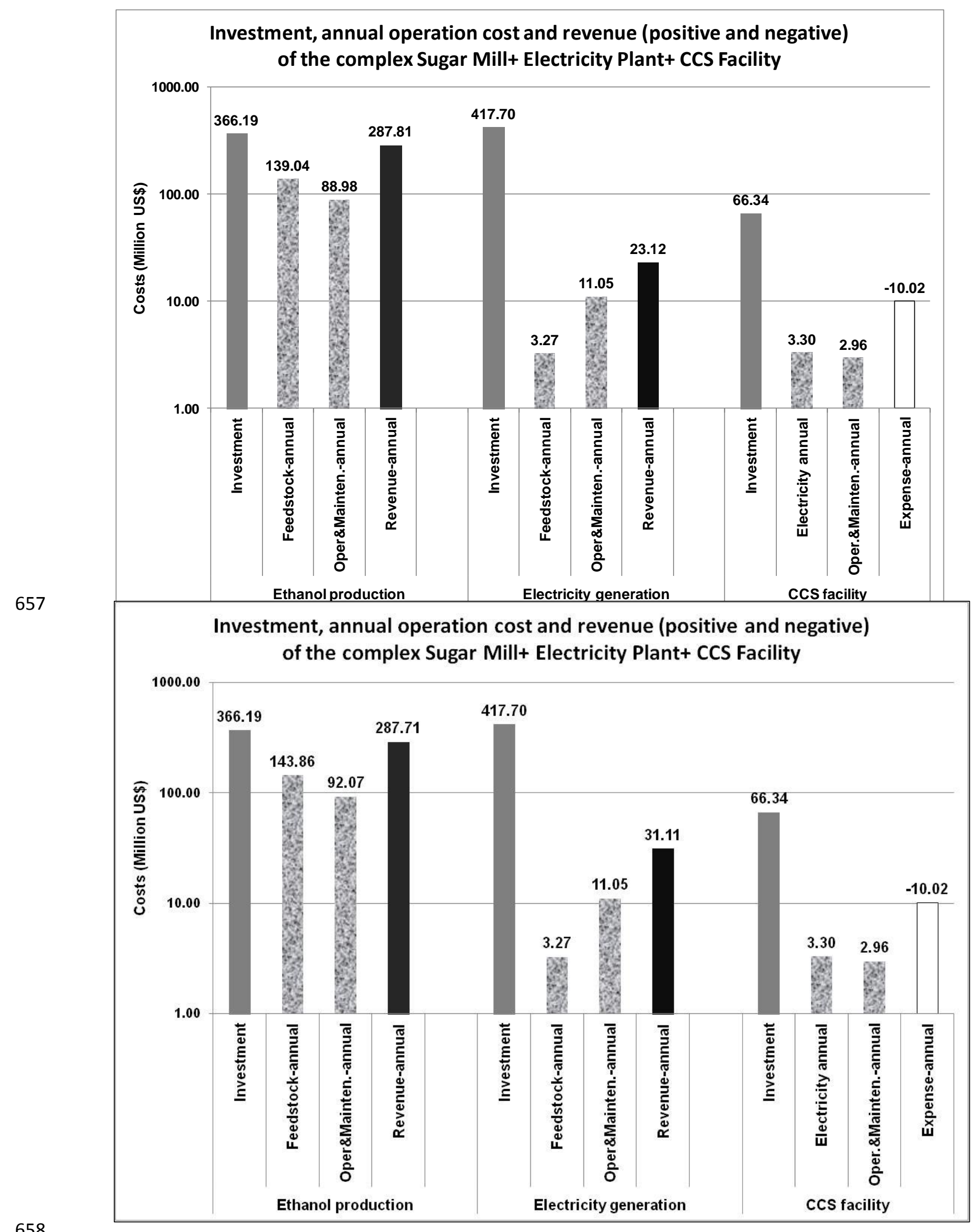


Figure S1 - Results from the financial model used in the calculation. Note: the value "Expense-annual" for CCS refers to a negative figure. Since the chart is displayed in logarithmic scale the value is presented as positive figure, but in blank color.

A calculation based on Table S3 parameters, in which a benchmark rate of return on equity of $6 \%$ above inflation is assumed for the investor, shows that the cost of $\mathrm{CO}_{2} \mathrm{CCS}$ is US\$ $30.29 / \mathrm{tCO}_{2}$.

In order to compensate the investor for this $\mathrm{CO}_{2}$ cost, ethanol has to be sold at the sugar mill gate at US\$ 0.621 , and bioelectricity sold to the grid $^{16}$ at a price US\$ 26.76/MWh without accounting for taxes. As noted, comparing to the cost calculated at section 3.3, the $\mathrm{CO} 2$ value is $11.3 \%$ higher, even considering the modest interest rate on the loan, which is available for infrastructure projects, in Brazil, through the National Development Bank (BNDES).

This calculated $\mathrm{CO}_{2}$ cost is significant when compared to $\mathrm{CO}_{2}$ market price. In US, prices around US\$ 40/tCO $\mathrm{tC}_{2}$ are being considered by the government, but presently around US\$ 12.00 are accounted for in some projects (EIA, 2015). During part of the Kyoto Protocol agreement, projects were supported with $\mathrm{CO}_{2}$ shadow prices near US\$ 40/tCO 2 , but most of the time the price was around or even below US\$20. Thus, it is very clear that even this BECCS technology, in which the $\mathrm{CO}_{2}$ capture cost is almost zero, requires regulation or support, as already discussed in the main text, thus affecting the ethanol and/or bioelectricity final sales price.

\section{Sensitivity Analysis}

Figures S2 and S3 provide information regarding the sensitivity of our results with respect to 3 parameters of our model: a) financing interest rate; b) equity share on the investment; and c) expected rate of return on equity, essentially the project's degree of attractiveness for the investor. Figure S2 shows the value that has to be paid to the investor in order to install and operate the CCS facility while receiving the same revenue when the CCS facility doesn't exist.

\footnotetext{
${ }^{16}$ In reality, from the $208 \mathrm{kWh} /$ tcane generated in the complex sugar mill/bioelectricity plant, $40 \mathrm{kWh}$ is used on site. Thus, only $168 \mathrm{kWh} / \mathrm{tcane}$ is commercialized through the grid. In our model electricity self generated is not overpriced to pay for CCS costs.
} 

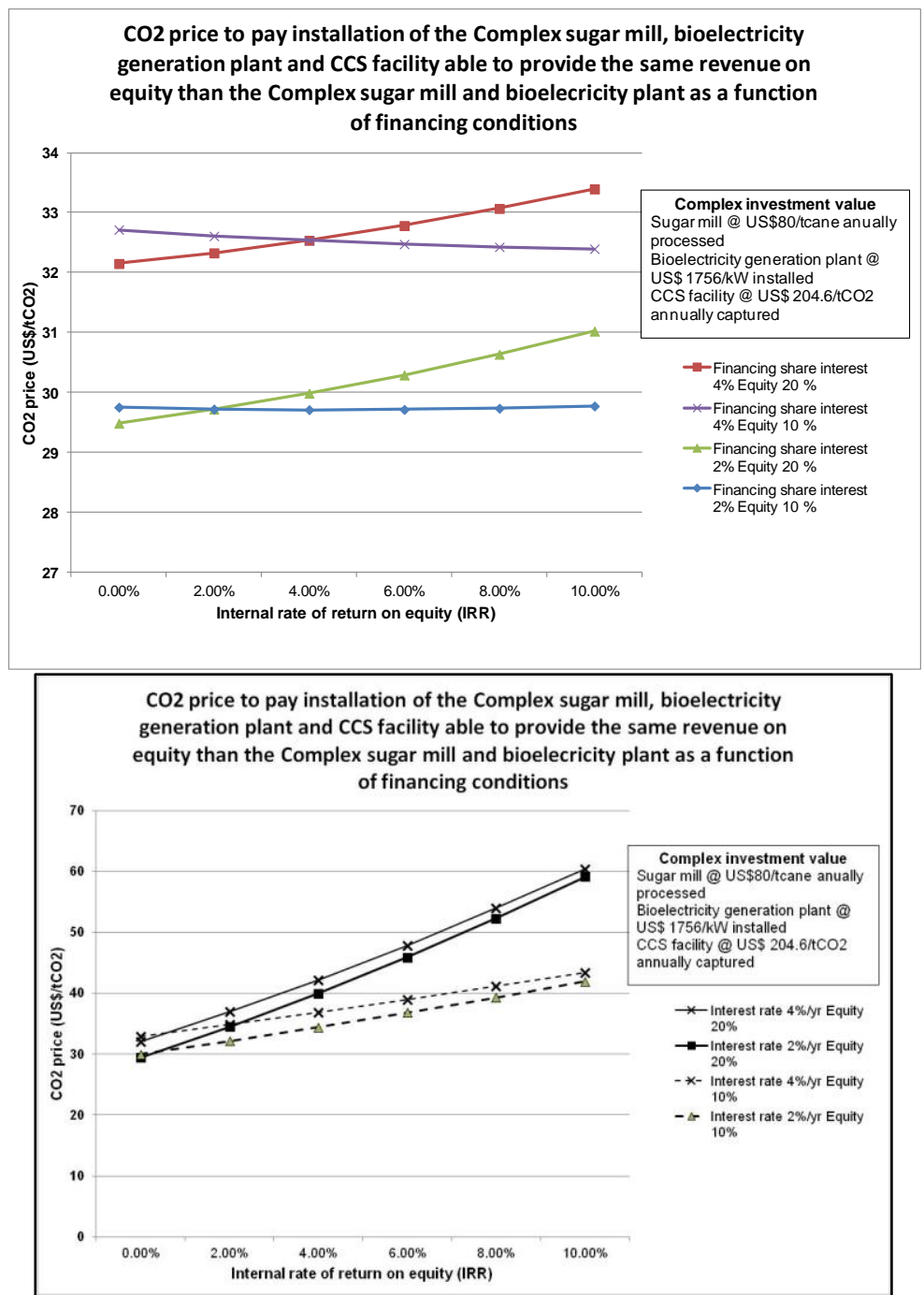

Figure $\mathrm{S} 2-\mathrm{CO}_{2}$ breakeven price to match the BECCS scheme given finance variable interest rates and equity shares. Source: Prepared by authors

Figure S3 shows bioelectricity sales price, at the electricity plant gate, without any taxes, for the investor recovering the CCS costs through sales of electricity and ethanol. This last product is sold at US\$ 0.621 , instead of the regular market price of US\$ 0.60 . 

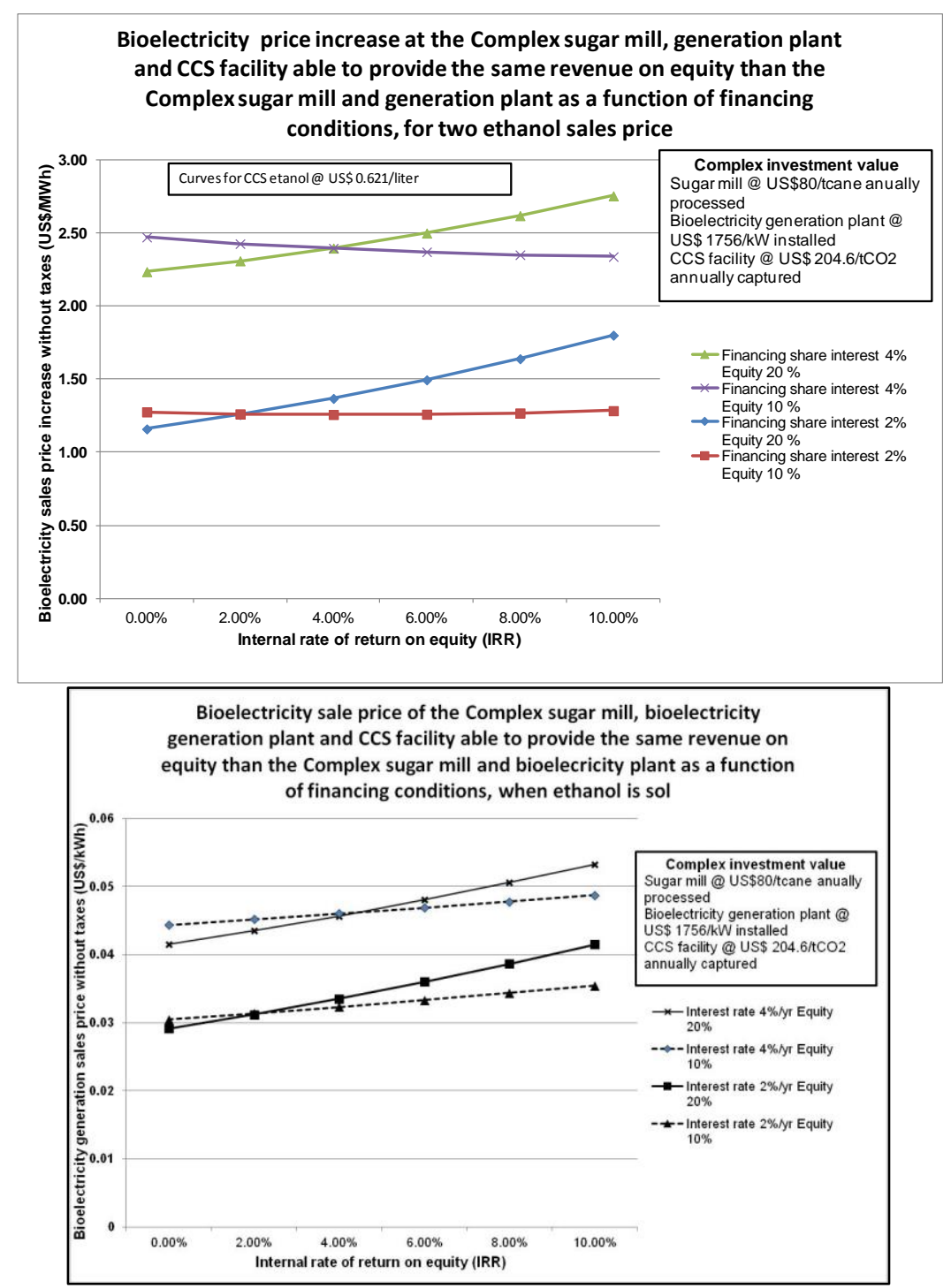

Figure S3 - Biolectricity sales price given variable interest rates and equity shares Source: Prepared by authors

\section{References}

ANP -Agência Nacional de Petróleo, Gás Natural e Biocombustíveis, 2013. BOLETIM ANUAL DE PREÇOS 2013 - preço s d o petról e o, gás n atura le com b u s tí v e i s nos mer cados nacional e internacional, Ministry of Mines and Energy, Rio de Janeiro, Brazil

EIA- Energy Information Administration, 2015. California and Quebec complete second joint carbon dioxide emissions allowance auction, March11, 2015, http://www.eia.gov/todayinenergy/detail.cfm?id=20312

EPE- Empresa de Pesquisas Energéticas, 2013. Anuário estatístico de energia elétrica 2013, Empresa Pesqisa Energética, Ministry of Mines and Energy, Brazil.

FIRJAN, 2012. A perspectiva de renovação das concessões, a redução de encargos e tributos e o impacto sobre o custo da energia elétrica para a indústria no Brasil, Nota Tecnica N0. 2, August 2012, Diretoria de Desenvolvimento Economico, Gerência de Competitividade Industrial e Investimentos, http://www.firjan.org.br/data/pages/2C908CEC38BA9D9E0138FD9F8C0125F5.htm, accessed April 8, 2015 
Gollakota, S and McDonald, S. (2014) Commercial-Scale CCS Project in Decatur, Illinois Construction Status and Operational Plans for Demonstration, Energy Procedia 63 ( 2014 ) 5986 5993

Instituto Acende Brasil (2011). Tarifas de Energia e os Benefícios da Regulação por Incentivos. White Paper 3, São Paulo, 24 p, Edition No. 3, January 2011

Jones, Rosalind A. and McKaskle, Ray W, 2014. Design and operation of compression system for one million tonne CO2 sequestration test Greenhouse Gases: Science and Technology 2014 Vol: 4 (5):617-625, doi: 10.1002/ghg. 1438

Marques, Pedro V., 2008. Custos de produção de cana-de-açúcar, açúcar e etanol no Brasil, safra 2007/2008, Piracicaba, SP, Brazil, p 198

MME, 2012. A-5/2012: Leilão de geração para 2017 contrata usinas hidrelétricas e parques eólicos,

http://www.google.com/url?sa=t\&rct=j\&q=\&esrc=s\&source=web\&cd=1\&cad=rja\&uact=8\&ved= 0CCEQFjAA\&url=http\%3A\%2F\%2Fwww.epe.gov.br\%2Fleiloes\%2FPaginas\%2FLeil\%25C3\%2 5A3o\%2520de $\% 2520$ Energia\%2520A-5\%25202012\%2FA52012Leil\%25C3\%25A3odegera\%25C3\%25A7\%25C3\%25A3opara2017contratausinashidrel\%25 C3\%25A9tricaseparquese\%25C3\%25B3licos.aspx\%3FCategoriaID\%3D6801\&ei=4ogmVfyYHo PvsAXnlICQAQ\&usg=AFQjCNGeg0EpL M6qeP7ukwWatWG5UsA9g\&bvm=bv.90237346,d.e $\underline{\mathrm{XY}}$, accessed by April 8, 2015

PETROBRAS, 2015. Composição de preços ao consumidor, Based in data from ANP and CEPEA/USP, http://www.google.com/url? sa=t\&rct=j\&q=\&esrc=s\&source=web\&cd=2\&cad=rja\&uact=8\&ved= 0CCgQFjAB\&url=http\%3A\%2F\%2Fwww.petrobras.com.br\%2Fpt\%2Fprodutos-eservicos $\% 2$ Fcomposicao-deprecos\%2Fgasolina\%2F\&ei=XJUmVbWPKoi5sAXPkYCgBg\&usg=AFQjCNEqkgqgQuVNgQVs j6vRW5TB2eYqZg, accessed by April 8, 2015 